\title{
Wojciech Żukrowski
}

Uniwersytet Ekonomiczny we Wrocławiu

e-mail: wojciech.zukrowski@ue.wroc.pl

\section{WPLYW PODATKU OD TOWARÓW I USEUG NA DOCHODY BUDŻETU PAŃSTWA A PROBLEM ŚCIĄGALNOŚCI}

\section{THE INFLUENCE OF VALUE ADDED TAX \\ ON THE REVENUE OF THE STATE BUDGET VS. A PROBLEM WITH THE COLLECTION OF TAXES}

DOI: $10.15611 /$ pn.2018.528.25

JEL Classification: H2

Streszczenie: Wśród wszystkich podatków największy wpływ na dochody budżetowe państwa wykazuje podatek od towarów i usług. Artykuł stanowi próbę przeanalizowania tematyki tego podatku oraz jego wpływu na dochody budżetowe państwa. Przeprowadzono analizę opartą na danych pochodzących ze strony internetowej Ministerstwa Finansów, opublikowane jako sprawozdania roczne z wykonania budżetu państwa z lat 2003-2017. Celem artykułu jest zweryfikowanie hipotezy o wzroście wartości dochodów z podatku od towarów i usług w sumie dochodów budżetowych państwa w roku 2017. W artykule wykazano, że w 2016 nastąpiły zmiany w przepisach podatkowych. Przeprowadzona analiza danych z wpływów podatkowych z roku 2016 i 2017 (do listopada) w ujęciu miesięcznym pokazała ponad 20 miliardów złotych wzrostu wpływów z podatku VAT, co oznacza, że metody uszczelniania podatku VAT z roku 2016 wpłynęły w sposób znaczący na poprawę ściągalności tego podatku.

Słowa kluczowe: podatek od towarów i usług, budżet, dochód

Summary: Among all taxes, the value added tax shows the greatest impact on state budget revenues. The article is an attempt to analyze the subject of the value added tax and its impact on the state budget revenues on the basis of available economic literature, legal provisions and data provided by the Ministry of Finance. The study carried out an analysis based on data from the website of the Ministry of Finance, published as annual reports on the implementation of the state budget from 2003-2017. The aim of the article is to verify the hypothesis about the increase in the value of income from the value added tax in the sum of state budget revenues in 2017. The article shows that in 2016 there were changes in tax regulations. The analysis of data from tax revenues from 2016 and 2017 (only to November) on a monthly basis showed over PLN 20 billion increase in VAT receipts, which means that the methods of sealing VAT from 2016 significantly affected the recovery of this tax.

Keywords: value added tax, budget, income. 


\section{Wstęp}

Podatki są nieodłącznym elementem funkcjonowania państwa. Jest to powszechne narzędzie wpływania przez państwo na gospodarkę. Największe znaczenie mają jako podstawowe źródło dochodów budżetowych. Istota oraz funkcje podatków czynią $\mathrm{z}$ tego instrumentu fiskalnego narzędzie niezbędne w sprawnym i zrównoważonym rozwoju państwa. Artykuł jest próbą przeanalizowania tematyki podatku od towarów i usług oraz jego wpływu na dochody budżetowe państwa na podstawie dostępnej literatury ekonomiczej, przepisów prawnych i danych udostępnionych przez Ministerstwo Finansów. Celem artykułu jest zweryfikowanie hipotezy o wzroście wartości dochodów z podatku od towarów i usług w sumie dochodów budżetowych państwa w roku 2017, a także weryfikacja wprowadzenia nowych metod służących poprawie ściągalności podatku od towarów i usług. Problemem badawczym nakreślonym $\mathrm{w}$ artykule jest uszczelnianie systemu podatkowego, mające na celu zwiększenie wpływów budżetowych. Jest to istotny problem, gdyż podatki, a szczególnie opisany w artykule podatek od towarów i usług, w bardzo dużym stopniu wpływają na dochody budżetowe, a następnie na zadania, jakie realizuje państwo. W artykule omówiono przesłanki historyczne wprowadzenia podatków, funkcje podatków w kontekście ekonomicznym oraz bliżej zapoznano się z podatkiem od towarów i usług, zwracając uwagę na jego przedmiot, podmiot oraz technikę opodatkowania. Wszystkie te kroki zostały podjęte w celu bliższego zrozumienia struktury opisanego podatku. W dalszej części przedstawiono analizę opartą na danych pochodzących ze strony internetowej ministerstwa finansów, opublikowane jako sprawozdania roczne z wykonania budżetu państwa. Do analizy wykorzystano dane z lat 2003-2017. Następnie zwrócono uwagę na problem ściągalności podatków oraz metody, które wprowadzono w 2016 roku w celu uszczelnienia systemu podatkowego w Polsce. Na zakończenie zaprezentowano analizę wpływów budżetowych podatku od towarów i usług w roku 2017 i porównano to zestawienie z rokiem poprzednim. Wyciągnięte wnioski zaprezentowano na podstawie analizy opracowanych przez autora wykresów.

\section{Funkcje podatków}

Obciążenia podatkowe są nieodłącznym elementem naszego życia. Szczególne znaczenie mają w funkcji podstawowego źródła dochodów w budżecie państwa, dlatego są jednym z podstawowych instrumentów wpływania przez państwo na gospodarkę. Ze względu na swoją powszechność obejmują swoim zakresem osoby prawne, osoby fizyczne oraz jednostki organizacyjne [Krajewska 2012, s. 98].

Pojawienie się podatków sięga historycznie początków rozwijania się życia społecznego w cywilizacji. Jako przyczynę powstania pierwszych form obciążających ludność finansowo można wymienić: konieczność finansowania osób zaangażowanych w rządzenie krajem, ustalenie porządku prawnego w państwie oraz stworzenie 
warunków bezpieczeństwa w państwie. Pierwszą z takich form obciążenia finansowo ludności były daniny publiczne ponoszone początkowo przez rolników i mieszczaństwo, w późniejszym okresie zaś przez duchowieństwo i szlachtę. Przedmiotem takiej daniny publicznej były w początkowym okresie dobra pobierane $\mathrm{z}$ natury, czyli zboże, sól, owoce itd., następnie kruszce i aż do dnia dzisiejszego pieniądze [Wolański 2007, s. 15].

Istotne znaczenie obciążeń podatkowych wiąże się z prowadzoną działalnością gospodarczą. Osoby prowadzące przedsiębiorstwo z jednej strony są podatnikami, a więc zobowiązują się do rozliczenia zobowiązań na rzecz publicznych podmiotów, np. Skarbu Państwa, jednostek samorządu terytorialnego, z drugiej strony są płatnikami, a więc ich zobowiązania polegają na obliczaniu, pobieraniu oraz rozliczaniu podatków w imieniu zatrudnionych pracowników.

Definicja podatku zawarta jest w art. 6 Ustawy z dnia 29 sierpnia 1997 roku Ordynacja podatkowa. Według zapisu w ustawie podatkiem jest każdorazowe nieodpłatne, przymusowe oraz bezzwrotne świadczenie pieniężne, mające charakter publicznoprawny, na rzecz Skarbu Państwa bądź danej jednostki samorządu terytorialnego. Podatkom przypisuje się trzy funkcje: fiskalną, regulacyjną i stymulacyjną [Brzeziński 2008, s. 112-114].

Funkcja fiskalna to najstarsza $\mathrm{z}$ funkcji podatków. Według tej funkcji podatki powinny odgrywać główną rolę w zasilaniu dochodów budżetowych. Funkcja ta ma charakter powszechny, czyli spełnia ją każdy podatek. Funkcja regulacyjna polega na kształtowaniu dochodu i majątku będących w dyspozycji podatnika. Część tych dochodów jest przesuwana w postaci podatków od podmiotów gospodarujących do budżetu państwa. Funkcja regulacyjna ma za zadanie przeciwdziałać nadmiernym, społecznie nieuzasadnionym rozwarstwieniom dochodów w społeczeństwie i sprawiedliwie rozkładać skutki transformacji na wszystkie zawodowe grupy ludności. Funkcja stymulacyjna to takie skonstruowanie podatku, aby sprzyjał on gospodarczym działaniom państwa, pobudzał do osiągania odpowiednich wyników i celów ekonomicznych i finansowych, a przede wszystkim sprzyjał podejmowaniu działań, które przynoszą zyski i pożądane efekty społeczne. Funkcja stymulacyjna wyznacza podatkowi cel ekonomiczny. Istnieje szereg możliwości realizacji tej funkcji. Do najważniejszych zaliczyć można system zwolnień i ulg podatkowych. Jest on kształtowany w taki sposób, by przyniósł pozytywne skutki dla państwa, a przede wszystkich dla podatnika [Gomułowicz, Małecki 2011, s. 134].

\section{Podatek od towarów i usług - konstrukcja podatku}

Podatek od towarów i usług (VAT) wraz z podatkiem akcyzowym znajduje się w tzw. grupie podatków obrotowych. Podatek VAT cechuje wielofazowość, powszechność oraz opodatkowanie konsumpcji. Jest on podatkiem wielofazowym od obrotu netto, począwszy od faz związanych z cyklem produkcyjnym aż po dystrybucję. Podatnik może odliczyć podatek naliczony w poprzedniej fazie obrotu od podatku należnego 
wykazanego w danej fazie obrotu. Podatnik oblicza należną kwotę podatku VAT (podatek należny) jako iloczyn podstawy opodatkowania i właściwej stawki VAT. Od podatku należnego potrąca kwotę podatku zapłaconego przy zakupach, wykazanego w fakturach zakupowych (podatek naliczony). Jeśli podatek należny przewyższa podatek naliczony, to powstaje obowiązek zapłaty ustalonej nadwyżki, w innym wypadku podatnik może rozliczyć różnicę w kolejnych okresach podatkowych, domagając się jej zwrotu. W Polsce VAT został wprowadzony zgodnie z Ustawą z dnia 8 stycznia 1993 roku o podatku od towarów i usług oraz o podatku akcyzowym [Ustawa z 8 stycznia 1993].

Opodatkowaniu podatkiem VAT podlegają: odpłatna dostawa towarów i odpłatne świadczenie usług na terytorium kraju, eksport towarów, import towarów na terytorium kraju, wewnątrzwspólnotowe nabycie towarów za wynagrodzeniem na terytorium kraju, wewmątrzwspólnotowa dostawa towarów [Litwińczuk 2013, s. 465-470].

Zakres podmiotowy podatku VAT obejmuje: osoby prawne, jednostki organizacyjne nie mające osobowości prawnej, osoby fizyczne wykonujące samodzielnie działalność gospodarczą [Podstawka 2017, s. 265-280].

Natomiast podatnikami nie są: organy administracji publicznej, organy administracji publicznej w zakresie realizowanych zadań, do których zostały one powołane.

Kwestie obowiązku podatkowego w Ustawie o podatku od towarów i usług z dnia 11 marca 2004 roku zostały uregulowane w art. 19. Artykuł ten wskazuje, że obowiązek podatkowy powstaje z chwilą wydania towaru lub z chwilą wykonania usługi. Ustawodawca polski określił też niektóre szczególne sytuacje, w których został inaczej określony moment powstania obowiązku podatkowego, tj. obowiązek podatkowy powstaje z chwilą wydania towarów - jeżeli podatnik wysyła towar nabywcy lub wskazanej przez niego osobie trzeciej; obowiązek podatkowy powstaje z chwilą wystawienia faktury - jeżeli dostawa towarów lub wykonanie usługi powinny być potwierdzone fakturą; obowiązek podatkowy powstaje $\mathrm{z}$ chwilą otrzymania przez podatnika zapłaty za wydany towar; obowiązek podatkowy powstaje z chwilą wymagalności opłat - jeżeli import towarów objęty jest procedurą celną; obowiązek podatkowy z tytułu importu towarów powstaje z chwilą objęcia towarów tą procedurą - w przypadku objęcia towarów procedurą celną; obowiązek podatkowy powstaje $\mathrm{z}$ chwilą powstania długu celnego - w imporcie towarów [Podstawka 2017, s. 255-260].

Podstawą opodatkowania jest wszystko to, co stanowi zapłatę za towary lub usługi, którą dostawca towarów lub usługodawca otrzymał lub otrzyma z tytułu sprzedaży od nabywcy, usługiobiorcy wraz z otrzymanymi dotacjami, subwencjami i dopłatami o zbliżonym charakterze. A więc wszystko to, co nie jest wyłączone z opodatkowania VAT, stanowi podstawę do naliczenia podatku [Maruchin 2013, s. 12-13].

W podatku od towarów i usług mają zastosowanie 3 rodzaje stawek podatkowych: stawka podstawowa: $23 \%$, stawka obniżona: 8 i $5 \%$, stawka zerowa: $0 \%$. 
Stawka VAT w wysokości 8\% ma zastosowanie m.in.: do towarów i usług wymienionych w załączniku nr 3 do ustawy o podatku od towarów i usług, np. do dostawy, budowy, remontu, modernizacji, termomodernizacji lub przebudowy obiektów budowlanych lub ich części zaliczonych do budownictwa objętego społecznym programem mieszkaniowym. Z dniem 1 stycznia 2011 roku wprowadzono do polskiego systemu VAT drugą stawkę obniżoną w wysokości 5\%. Listę towarów objętych stawką 5\% zawiera załącznik nr 10 do ustawy o VAT, który obejmuje podstawowe produkty żywnościowe (np. chleb, nabiał, przetwory mięsne, produkty zbożowe: mąka, kasze, makaron, soki), książki drukowane i wydawane na dyskach, taśmach i innych nośnikach oraz czasopisma specjalistyczne [Podstawka 2017, s. 255-260].

\section{Wpływ podatku VAT na dochody budżetowe}

Podatek od towarów i usług jest jednym z głównych składników dochodów podatkowych. Jak pokazuje tab. 1, wpływy z podatku od towarów i usług od 2003 roku wzrosły ponaddwukrotnie. Dochody podatkowe zaś rosną wprost proporcjonalnie do dochodów ogółem. Oznacza to, że właśnie wpływy z podatków mają największe znaczenie w budżecie centralnym państwa.

Tabela 1. Zestawienie dochodów z podatku od towarów i usług na tle dochodów podatkowych i dochodow ogółem w latach 2003-2016

\begin{tabular}{|c|c|c|c|}
\hline Rok & $\begin{array}{c}\text { Dochody ogółem } \\
\text { (w tys. zł) }\end{array}$ & $\begin{array}{c}\text { Dochody podatkowe } \\
\text { (w tys. zł) }\end{array}$ & $\begin{array}{c}\text { Dochody z wpływów } \\
\text { podatku VAT } \\
\text { (w tys. zł) }\end{array}$ \\
\hline 2016 & 314683570 & 273138413 & 126584120 \\
\hline 2015 & 289136706 & 259673511 & 123120798 \\
\hline 2014 & 283542707 & 254780985 & 124262243 \\
\hline 2013 & 279151205 & 241650924 & 113411541 \\
\hline 2012 & 287595114 & 248274572 & 120000697 \\
\hline 2011 & 277557221 & 243210936 & 120831951 \\
\hline 2010 & 250302781 & 222552687 & 107880327 \\
\hline 2009 & 274183500 & 214878835 & 99454721 \\
\hline 2008 & 253547261 & 219499380 & 101782739 \\
\hline 2007 & 236367532 & 206385202 & 96349847 \\
\hline 2006 & 197639812 & 174876010 & 84439484 \\
\hline 2005 & 179772217 & 155859545 & 75401029 \\
\hline 2004 & 156281202 & 135571258 & 62263184 \\
\hline 2003 & 152110586 & 135227631 & 60359518 \\
\hline
\end{tabular}

Źródło: opracowanie własne na podstawie sprawozdań z wykonania budżetu państwa z lat 2003-2016. 
Dochody $\mathrm{z}$ tego podatku obrotowego rosną systematyczne od ponad dekady. W roku 2016 dochody z tego tytułu wynosiły 126584120000 zł i były o ponad 3 miliardy złotych wyższe niż w roku 2015. Od 2003 roku, w którym to dochody $\mathrm{z}$ tego podatku wyniosły nieco ponad 60 miliardów złotych, wielkość środków wpływających do budżetu państwa z podatku VAT stale rośnie. Przedstawia to również poniższy rys. 1, ilustrujący wzrost wartości wpływów podatku od towarów i usług oraz dochodów podatkowych wraz z dochodami ogółem.

\section{Dochody państwa}

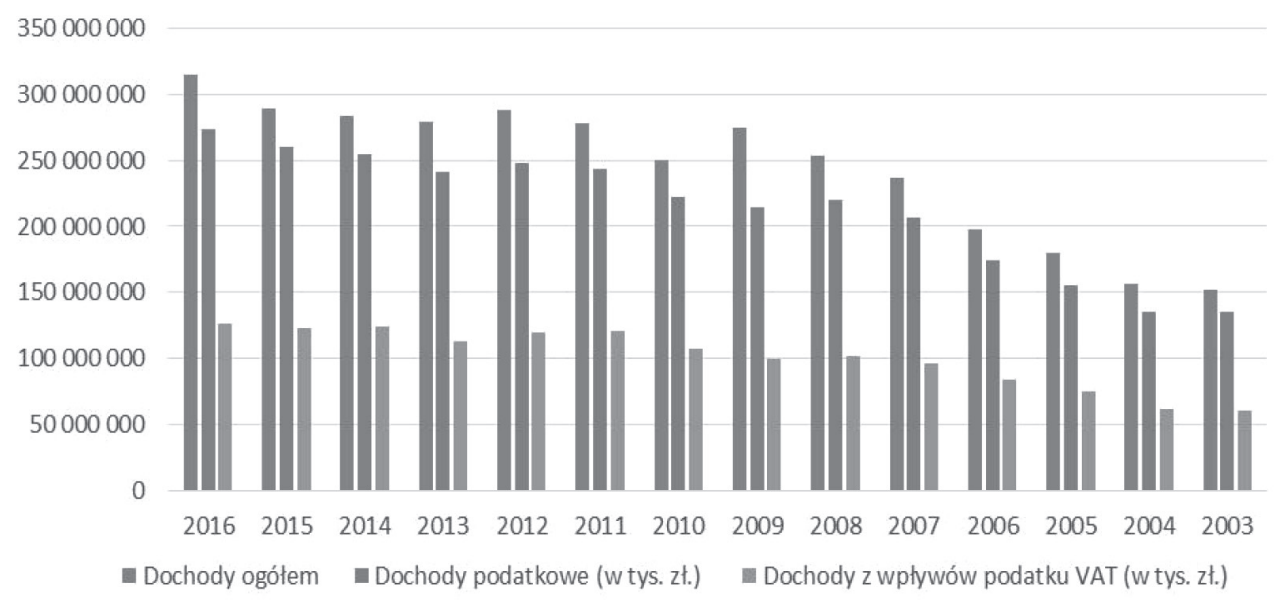

Rys. 1. Wartość wpływów z podatku od towarów i usług oraz dochodów podatkowych na tle dochodów ogółem w latach 2003-2016

Źródło: opracowanie własne na podstawie sprawozdań z wykonania budżetu państwa z lat 2003-2016.

Jak przedstawia rys. 1, dochody podatkowe są dominującym składnikiem wpływającym na wartość dochodów budżetowych państwa. Doskonale można zaobserwować tendencję rosnącą wpływów podatkowych do budżetu. W sposób procentowy dane $\mathrm{z}$ wykonania budżetu pokazuje tab. 2, przedstawiająca zestawienie procentowe zmian wpływów z dochodów podatkowych, a zwłaszcza dochodów od podatku od towarów i usług.

Jak pokazuje tab. 2, udział dochodów z podatku od towarów i usług w dochodach ogółem w roku 2016 kształtował się na poziomie $40 \%$ i był o 3 punkty procentowe mniejszy niż w roku poprzednim. Jednak jak pokazuje tendencja zmian, na przestrzeni 14 lat kształtował się on na poziomie około $40 \%$. Sam podatek od towarów i usług ma blisko 50\% udziału we wpływach dochodów podatkowych. Oznacza to, że połowa dochodów podatkowych wpływających do budżetu państwa pochodzi z wpływów podatku VAT. 
Tabela 2. Ujęcie procentowe zmian dochodów podatku od towarów i usług na tle dochodów podatkowych i dochodów ogółem w latach 2003-2016

\begin{tabular}{|c|c|c|}
\hline Rok & $\begin{array}{c}\text { Udział podatku VAT } \\
\text { w dochodach podatkowych } \\
\text { (podatek VAT/dochody podatkowe) }\end{array}$ & $\begin{array}{c}\text { Udział podatku VAT } \\
\text { w dochodach ogółem } \\
\text { (podatek VAT/dochody ogółem) }\end{array}$ \\
\hline 2016 & $46 \%$ & $40 \%$ \\
\hline 2015 & $47 \%$ & $43 \%$ \\
\hline 2014 & $49 \%$ & $44 \%$ \\
\hline 2013 & $47 \%$ & $41 \%$ \\
\hline 2012 & $48 \%$ & $42 \%$ \\
\hline 2011 & $50 \%$ & $44 \%$ \\
\hline 2010 & $48 \%$ & $43 \%$ \\
\hline 2009 & $46 \%$ & $36 \%$ \\
\hline 2008 & $46 \%$ & $40 \%$ \\
\hline 2007 & $47 \%$ & $41 \%$ \\
\hline 2006 & $48 \%$ & $43 \%$ \\
\hline 2005 & $48 \%$ & $42 \%$ \\
\hline 2004 & $46 \%$ & $40 \%$ \\
\hline 2003 & $45 \%$ & $40 \%$ \\
\hline
\end{tabular}

Źródło: opracowanie własne na podstawie sprawozdań z wykonania budżetu państwa z lat 2003-2016.

\section{Podatek od towarów i usług - problem ściągalności}

Podatek VAT jest podatkiem, który zapewnia największe wpływy budżetowe. Im większe wpływy do budżetu państwa, tym więcej pieniedzy dla państwa, a co za tym idzie, większe możliwości budżetowe. Według badań firmy audytorskiej PwC (PricewaterhouseCoopers) z roku 2016, luka podatkowa VAT wynosi blisko 3\% PKB. Dlatego tak ważne jest uszczelnienie przepisów podatkowych, zniwelowanie luki podatkowej oraz poprawienie ściągalności. Do działań mających na celu poprawienie ściagalności podatku VAT należą: wprowadzenie odpowiedzialności karnej za przestępstwa fakturowe, wprowadzenie sankcji podatkowych za nierzetelne rozliczanie podatku, wdrożenie jednolitego pliku kontrolnego oraz zwiększona liczba kontroli podatkowych.

Zmianie uległy kary wprowadzone do kodeksu karnego. Wprowadzono nowe kategorie przestępstw: wystawianie fikcyjnych faktur VAT oraz ich podrabianie i przedstawianie jako autentyczne. Wprowadzono dwie kary. Pierwsza dotyczy sfałszowanych faktur służących do wyłudzenia zwrotu VAT o wartości przekraczającej 10 milionów złotych: sprawcom grozić będzie nawet 25 lat pozbawienia wolności. Druga dotyczy wyłudzeń na kwotę przekraczającą 5 milionów złotych: sprawcom grozić będzię od 3 do 15 lat pozbawienia wolności. 
Na mocy ustawy z 1 grudnia 2016 r. o zmianie ustawy o podatku od towarów i usług oraz niektórych innych ustaw, do ustawy o VAT został dodany rozdział 5, w którym określono zasady ustalania dodatkowego zobowiązania podatkowego, czyli tzw. sankcji VAT. Ustawodawca wprowadził dwie stawki sankcyjne, tj. 30\% od stwierdzonej nieprawidłowości wynikającej z faktury oraz $100 \%$ od wartości VAT $\mathrm{w}$ razie stwierdzenia oszustwa podatkowego.

Jednolity Plik Kontrolny to księgi i dokumenty księgowe prowadzone za pomocą programów komputerowych w odpowiednim formacie, przekazywane na żądanie organu podatkowego. System ten pozwala urzędnikom na zlokalizowanie tzw. pustych faktur, a także na automatyzację procesów, zatem w sposób znaczący poprawia ściągalność.

W roku 2016 w Polsce przeprowadzono 22197925 kontroli podatkowych, z czego 90\% dotyczyło podatku VAT. W porównaniu do roku 2013, kiedy przeprowadzono 6446730 kontroli podatkowych, jest to niemal czterokrotny wzrost liczby przeprowadzonych kontroli.

Powyższe działania zostały wprowadzone w życie w roku 2016. Jak można wywnioskować z danych Ministerstwa Finansów, dochody podatku VAT w roku 2016 wzrosły o $3 \mathrm{mld}$ w stosunku do roku poprzedniego. Na pełną ocenę wprowadzonych zmian należy poczekać przynajmniej do połowy roku 2018. Jednak poniższa miesięczna analiza danych z roku 2016 i z roku 2017 wskazuje niewątpliwie na poprawę ściągalności podatku VAT. Tabela 3 przedstawia miesięczne ujęcie wpływów z podatku VAT w przeciągu roku 2016 i pierwszych 11 miesięcy roku 2017.

Tabela 3. Porównanie wpływów z podatku od towarów i usług w ujęciu miesięcznym w latach 2016-2017

\begin{tabular}{|l|c|c|}
\hline \multicolumn{1}{|c|}{ Miesiące } & $\begin{array}{c}\text { Rok 2016 } \\
\text { (w tys. zf) }\end{array}$ & $\begin{array}{c}\text { Rok 2017 } \\
\text { (w tys. zf) }\end{array}$ \\
\hline Styczeń & 17492026 & 21913287 \\
\hline Luty & 6429658 & 11607508 \\
\hline Marzec & 6226840 & 8876770 \\
\hline Kwiecień & 12426299 & 14431784 \\
\hline Maj & 10308525 & 11926545 \\
\hline Czerwiec & 9558191 & 11259067 \\
\hline Lipiec & 13581593 & 14556408 \\
\hline Sierpień & 10262605 & 11975096 \\
\hline Wrzesień & 9786965 & 11938929 \\
\hline Październik & 14059964 & 15499050 \\
\hline Listopad & 11341652 & 12204635 \\
\hline Grudzień & 5109802 & \\
\hline
\end{tabular}

Źródło: opracowanie własne na podstawie sprawozdań z wykonania budżetu państwa z lat 2003-2016. 
Z tabeli 3 można wywnioskować, że dochody z podatku VAT w poszczególnych miesiącach roku 2017 były zdecydowanie wyższe w ujęciu miesięcznym niż w roku 2016. W samym styczniu wpływ z podatku VAT był większy niż w roku poprzednim o blisko 4,5 miliarda złotych, czyli blisko $25 \%$. W lutym wpływy z podatku VAT wzrosły o ponad 5 miliardów złotych w stosunku do roku ubiegłego. W pozostałych miesiącach można zaobserwować stałą tendencję wzrostową. W każdym miesiącu następował wzrost na poziomie ok. 2 miliardów złotych w stosunku do roku ubiegłego. Łączna kwota wpływów z podatku VAT w roku 2017 (do listopada) wyniosła ponad 144 miliardy złotych, czyli o ponad 20 miliardów złotych więcej niż w roku 2016.

\section{Zakończenie}

Artykuł przedstawia analizę wpływu podatku od towarów i usług na dochody budżetowe państwa, zwracając uwagę na problem jego ściągalności. Celem pracy była weryfikacja hipotezy o poprawie ściągalności podatku VAT w roku 2017 po zmianach wprowadzonych w roku poprzedzającym.

Podatek jest rozpatrywany w kategoriach prawno-ekonomicznych. Podatek jako kategoria ekonomiczna wyraża się w przejęciu na rzecz państwa lub związków publicznoprawnych od podmiotów im podporządkowanych części ich przychodów, dochodów lub majątku. W zestawie podatków obrotowych wyróżnia się podatek od towarów i usług oraz podatek akcyzowy.

Podatek od towarów i usług to najbardziej wartościowy podatek ze wszystkich w polskim prawie podatkowym. Jego wpływy stanowią w sposób dominujący o dochodach budżetowych. Na podstawie analizy z lat 2003-2016 można wnioskować, że udział uzyskiwanych dochodów jest na stałym, stabilnym poziomie około $40 \%$ wszystkich dochodów budżetowych. Jak wykazała przeprowadzona analiza na podstawie dostępnych materiałów, podatek VAT to dominujący czynnik kształtowania się wpływów z podatków ogółem na poziomie blisko 50\%. Podatek ten jest elementem ważnym w procesie ustalania budżetu państwa, gdyż w sposób dominujący wpływa na jego dochody.

Istotnym czynnikiem wpływającym na wielkość wpływów z podatku VAT są sposoby jego uszczelniania. Niezwykle ważna jest poprawa ściągalności i zniwelowanie luki podatkowej. W artykule zweryfikowano hipotezę badawczą o poprawie ściągalności podatku od towarów i usług. W roku 2016 nastąpiły zmiany w przepisach podatkowych wprowadzające następujace usprawnienia: wprowadzenie odpowiedzialności karnej za przestępstwa fakturowe, wprowadzenie sankcji podatkowych za nierzetelne rozliczanie podatku oraz wdrożenie jednolitego pliku kontrolnego i zwiększenie liczby kontroli podatkowych.

Przeprowadzona analiza danych z wpływów podatkowych z roku 2016 i 2017 (do listopada) w ujęciu miesięcznym pokazała ponad 20 miliardów złotych wzrostu wpływów z podatku VAT, co oznacza, że metody uszczelniania podatku VAT z roku 
2016 wpłynęły w sposób znaczący na poprawę ściągalności tego podatku. Zatem hipoteza o poprawie ściągalności i wzroście wpływów budżetowych wynikających z opodatkowania została zweryfikowana pozytywnie.

Biorąc pod uwagę dynamiczny wzrost wpływów podatkowych w roku 2017, można oczekiwać zwiększenia znaczenia w ujęciu procentowym podatków w dochodach budżetowych państwa. Oznacza to, że dochody podatkowe dalej będą w sposób dominujący wpływać na dochody budżetowe, a podatek od towarów i usług będzie miał największe znaczenie.

\section{Literatura}

Brzeziński B., 2008, Podstawy wykładni prawa podatkowego, ODDK, Warszawa.

Gomułowicz A., Małecki J., 2011, Podatki i prawo podatkowe, Lexis Nexis, Warszawa.

Krajewska A., 2012, Podatki w Unii Europejskiej, PWE, Warszawa.

Litwińczuk H., 2013, Prawo podatkowe przedsiębiorców, LEX, Warszawa.

Maruchin W., 2013, System podatkowy, Vizja Press, Warszawa.

Ministerstwo Finansów, 2018, Sprawozdania z wykonania budżetu państwa (roczne) z lat 2000-2017, https://www.mf.gov.pl (18.04.2018).

Podstawka M., 2017, Finanse, PWN, Warszawa.

Ustawa z dnia 8 stycznia 1993 r. o podatku od towarów i usług oraz o podatku akcyzowym, Dz.U. 1993, nr 11, poz. 50 .

Wolański R., 2007, System podatkowy w Polsce, Oficyna Wolters Kluwer Polska, Warszawa. 